\title{
Analisa Bangkitan Perjalanan Perumahan Villa Indah Permai dan Villa Dago Permai di Kecamatan Baturaja Timur Kabupaten Ogan Komering Ulu
}

\author{
Ferry Desromi $^{1)}$ \\ ${ }^{1)}$ Jurusan Teknik Sipil Fakultas Teknik Universitas Baturaja \\ Jl. Ratu Penghulu No. 02301 Karang Sari Baturaja 32115 \\ Email :ferry_desromi@yahoo.com ${ }^{1)}$
}

\begin{abstract}
The emergence of a residential area causes a change in the function of land use, which in the future causes many problems. The daily activities of the community to carry out activities such as parents going to work, mothers going to the market and students going to school, as well as other activities certainly lead to trip generation that will burden the network paths to the activity centers. The multiple linear analysis method is used to produce relationships in numerical form and to see how variables are interrelated. To analyze data using descriptive qualitative. Regression analysis is useful to determine the trip generation model and the model obtained can be known the factors that influence trip generation and predict the housing traffic conditions of Villa Indah Permai and Villa Dago Permai. To obtain maximum results and facilitate data processing, the analysis process uses computer software with the SPSS (Statistical Product and Service Solution) program. Based on the results of the t test for income (X1) obtained T count of 3.282 is greater than t table 2.00665 and with a significance level of $0.002<0.05$. Thus Ha was accepted and Ho was rejected. Based on the results of the t test for the age of the head of the family (X3) obtained a count of 3.302 smaller than $t$ table 2.00665 and with a significance level of $-1.100<0.05$. Thus Ha was accepted and Ho was rejected. Based on the results of the $t$ test for four-wheeled vehicles. (X4) obtained $T$ count of 6.386 is greater than $t$ table 2.00665 and with a significance level of $0.000<0.05$. Thus Ha was accepted and Ho was rejected
\end{abstract}

Keywords : Trip generation, Villa Indah Permai housing, Villa Dago Permai housing, multiple linear regression

\begin{abstract}
ABSTRAK
Munculnya kawasan perumahan menyebabkan berubahnya fungsi tata guna lahan yang kemudian hari banyak menimbulkan permasalahan. Kegiatan sehari-hari masyarakat untuk melakukan aktifitas seperti orang tua pergi bekerja, ibu pergi kepasar dan pelajar berangkat sekolah, serta kegiatan lainnya tentu menyebabkan timbulnya bangkitan-bangkitan perjalanan yang akan membebani jalur-jalur jaringan menuju pusat-pusat kegiatan. Metode analisis linear berganda digunakan untuk menghasilkan hubungan dalam bentuk numerik dan untuk melihat bagaimana variabel saling berkait. Untuk menganalisa data dengan menggunakan deskriptif kualitatif. Analisa regresi berguna untuk mengetahui model bangkitan perjalanan dan model yang didapat bisa diketahui faktor-faktor yang mempengaruhi bangkitan perjalanan serta memprediksi kondisi lalu lintas perumahan Villa Indah Permai dan Villa Dago Permai. Untuk memperoleh hasil yang maksimal dan mempermudah pengolahan data, maka dalam proses analisa menggunakan perangkat lunak komputer dengan program SPSS (Statistical Product and Service Solution). Berdasarkan hasil uji t untuk penghasilan (X1) diperoleh T hitung sebesar 3,282 lebih besar dari t tabel 2,00665dan dengan tingkat signifikasi sebesar 0,002 <0,05. Dengan demikian Ha diterima dan Ho ditolak. Berdasarkan hasil uji $t$ untuk umur kepala keluarga (X3) diperoleh hitung sebesar 3,302 lebih kecil dari t tabel 2,00665dan dengan tingkat signifikasi sebesar -1,100 < 0,05. Dengan demikian Ha diterima dan Ho ditolak. Berdasarkan hasil uji $t$ untuk kendaraan roda empat. (X4) diperoleh T hitung sebesar 6,386 lebih besar dari t tabel 2,00665dan dengan tingkat signifikasi sebesar 0,000 <0,05. Dengan demikian Ha diterima dan Ho ditolak
\end{abstract}

Kata kunci : Bangkitan perjalanan, perumahan Villa Indah Permai, perumahan Villa Dago Permai, regresi linear berganda 


\section{Pendahuluan}

\section{A. Latar Belakang}

Permasalahan bangkitan perjalanan merupakan akibat dari pertumbuhan penduduk yang sangat pesat, peningkatan jumlah kendaraan bermotor, serta terbatasnya fasilitas jaringan jalan yang ada merupakan faktor yang perlu diperhatikan. Ketidakseimbangan antara sistem kegiatan dari suatu tata guna lahan, Sistem jaringan dan sistem pergerakan transportasi tersebut merupakan sebuah mata rantai yang akan terus berlanjut sebagai akibat dari perkembangan kota yang dinamis.

Keberadaan perumahan Villa Indah Permai dan Villa Dago Permai dikawasan kecamatan Baturaja Timur kabupaten Ogan Komering Ulu, sebagai kawasan / tata guna lahan yang tentunya akan dapat meningkatkan bangkitan perjalanan. Meningkatnya jumlah perjalan yang dibangkitkan oleh lokasi perumahan tersebut.

Munculnya kawasan perumahan menyebabkan berubahnya fungsi tata guna lahan yang kemudian hari banyak menimbulkan permasalahan. Kegiatan seharihari masyarakat untuk melakukan aktifitas seperti orang tua pergi bekerja, ibu pergi kepasar dan pelajar berangkat sekolah, serta kegiatan lainnya tentu menyebabkan timbulnya bangkitan-bangkitan perjalanan yang akan membebani jalur-jalur jaringan menuju pusatpusat kegiatan.

\section{B. Perumusan Masalah}

Adapun rumusan masalah dari latar belakang diatas yaitu " Bagaimana menganalisa bangkitan perjalanan perumahan Villa Indah Permai dan Villa Dago Permai dikecamatan Baturaja Timur kabupaten Ogan Komering Ulu?"

\section{Manfaat Penelitian}

1. Dapat menjadi referensi bagi pihak lain yang ingin melakukan penelitian dikemudian hari.

2. Informasi yang terangkum dapat dijadikan salah satu dasar pertimbangan bagi perencanaan dan pemerintah dalam menentukan kebijakan terhadap masalah bangkitan perjalanan dan pengembangan prasarana kota Baturaja OKU, khususnya untuk wilayah perumahan dikecamatan Baturaja Timur.

\section{Tujuan Penelitian}

Tujuan dari penelitian ini adalah untuk mengetahui jumlah fluktuasi satuan mobil penumpang per jam serta pemodelan bangkitan perjalanan perumahan Villa Indah Permai dan Villa Dago Permai.

\section{E. Batasan Masalah}

Guna mencapai maksud dan tujuan yang diinginkan, maka perlu ditentukan batasan masalah agar pembahasan lebih terarah, untuk itu penulis hanya membahas masalah bangkitan perjalanan perumahan Villa Indah Permai dan Villa Dago Permai yang berada dikawasan kecamatan Baturaja Timur kabupaten Ogan Komering Ulu.
F. Tinjauan Pustaka

1. Tinjauan Penelitian Sebelumnya

Michael Octavianus, (2013). Pada penelitiannya yang berjudul bangkitan perjalanan pada perumahan menteng indah di kecamatan medan denai, menyimpulkan bahwa Pertumbuhan penduduk yang semakin besar merupakan akibat dari perkembang kota dan industrialisasi terutama di beberapa kota yang ada di Indonesia yang memberi dampak yang sangat berpengaruh terhadap kota tersebut terutama pemanfaatan tata guna lahan. Tujuan penulisan tugas akhir ini adalah mengidentifikasikan faktor-faktor yang mempengaruhi terjadinya bangkitan perjalanan dari komplek perumahan Menteng Indah Medan. Mendapatkan jumlah bangkitkan perjalanan oleh penghuni komplek perumahan Menteng Indah Medan ketempat beraktivitas dengan menggunakan kendaraan pribadi (mobil dan sepeda motor). Metode analisis yang digunakan adalah metode analisis regresi linear berganda dengan uji statistik dan metode analisa kategori (klasifikasi silang).

Penelitian ini bertujuan untuk mengetahui karakteristik dan jumlah bangkitan perjalanan dari suatu zona ke Mall of Serang. Metode yang dilakukan dalam penelitian ini adalah survei dengan pengisian kuesioner ke-416 responden yang berasal dari dua zona pergerakan yaitu zona internal dan zona eksternal. Hasil dari kuesioner kemudian ditabulasikan selanjutnya dianalisis menggunakan analisis klasifikasi silang (cross clasification). Hasil penelitian menunjukkan bahwa jumlah bangkitan perjalanan zona yang terjadi adalah sebanyak 318 rumah tangga dari zona internal yang melakukan perjalanan/hari. Sedangkan untuk pergerakan dari zona eksternal sebesar 91 rumah tangga yang melakukan perjalanan/hari. Sehingga total jumlah bangkitan perjalanan zona terhadap Mall of Serang adalah 409 perjalanan/hari. Berdasarkan jumlah bangkitan perjalanan zona yang terjadi dapat pula diperkirakan jumlah moda transportasi yang digunakan saat menuju Mall of Serang, yaitu untuk mobil diketahui sebanyak 82 pergerakan, sepeda motor 237 pergerakan, angkutan umum 78 pergerakan dan untuk para pejalan kaki serta kendaraan tak bermotor non sebanyak 8 pergerakan.

\section{G. Landasan Teori}

1. Bangkitan Perjalanan/ Pergerakan

Bangkitan perjalanan/pergerakan yang terjadi merupakan perkiraan jumlah perjalanan yang tertarik kesuatu tata guna lahan atau zona, dimana merupakan fungsi tata guna lahan yang menghasilkan pergerakan lalu lintas. Bangkitan perjalanan mencakup tentang perjalanan yang meninggalkan suatu lokasi dan perjalanan menuju lokasi tersebut.

Bangkitan perjalanan merupakan tahap pemodelan transportasi yang bertugas untu memperkirakan dan meramalkan jumlah perjalanan yang berasal dari suatu zona/kawasan dan jumlah perjalanan yang datang/tertarik ke suatu zona/kawasan pada masa yang akan datang per satuan waktu (Miro 2005) 


\section{H. Metode Analisis Data}

Alat analisa data yang digunakan dalam penelitian ini menggunakan pendekatan kuantitatif. Penelitian kuantitatif merupakan suatu penelitian yang analisanya secara umum memakai analisis statistik, baik pengujian analisis statistik tersebut menggunakan perhitungan secara manual (menggunakan rumus) maupun perhitungan berbasis komputer (menggunakan program spss).

Teknik analisis yang digunakan dalam penelitian ini adalah analisis regresi linear berganda, alasan penelitian ini adalah karena penelitian ini mencari pengaruh sehingga yang cocok digunakan adalah regresi linear berganda. Sebelum melakukan pengujian hipotesis dengana analisis regresi linear berganda perlu dilakukan uji asumsi klasik terlebih dahulu sehingga menghasilkan analisis regresi linear berganda dengan estimasi yang baik.

\section{Statistik Deskriptip}

Dalam penelitian ini digunakan untuk memberikan deskripsi atau gambaran yang dilakukan untuk mempermudah dalam memahami variabel-variabel yang digunakan dalam penelitian minimum.

\section{J. Uji Asumsi Klasik}

Suatu model regresi berganda yang digunakan untuk menguji hipotesis harus memenuhi uji asumsi klasik. Hal ini digunakan untuk menghindari estimasi yang bisa, mengingat tidak semua data dapat diterapkan regresi. Uji asumsi klasik terdiri dari uji normalitas, uji multikolinearitas, uji heteroskadastisitas dan uji autokorelasi.

\section{K. Uji Multikolinearitas}

Bertujuan untuk menguji apakah dalam model regresi ditemukan adanya korelasi antara variabel bebas (Ghozali, 2011). Model regresi yang baik seharusnya tidak terjadi korelasi diantara variabel bebas, model regresi yang normal memiliki batas angka tolerance value lebih besar dari 0,10 sedangkan batas nila VIF diatas 10 dan mempunyai angka mendekati 1 .

\section{Uji Heteroskadastisitas}

Bertujuan untuk menguji apakah dalam model regresi terjadi ketidaksamaan variance dari residual satu pengamatan ke pengamatan yang lain tetap, maka disebut homoskadastisitas dan jika berbeda disebut heteroskadastisitas. Model regresi yang baik adalah homoskadastisitas atau tidak terjadi heteroskadastisitas.

Sebaliknya, jika nilai $\mathrm{r}$ yang mendekati +1 mempunyai arti bahwa kedua variabel tersebut saling berkorelasi positif (peningkatan nilai salah satu variabel akan menyebabkan peningkatan nilai variabel lainnya). Jika nilai $\mathbf{r}$ mendekati $\mathbf{0}$, tidak terdapat korelasi antara kedua variabel tersebut (Tamin, 2008;29).

\section{Regresi Linear Berganda}

Dalam pemodelan bangkitan perjalanan, metode analisis regresi linear berganda (multiple Linear
Regression Analysis) yang paling sering digunakan baik data zona dan data rumah tangga atau individu. Metode analisis linear berganda digunakan untuk menghasilkan hubungan dalam bentuk numerik dan untuk melihat bagaimana variabel saling berkait.

Ada beberapa asumsi statistik harus dipertimbangkan dalam menggunakan metode analisis linear berganda, sebagai berikut:

1. Variabel terikat (Y) merupakan fungsi linear dari variabel bebas $(\mathrm{X})$.

2. Variabel, terutama variabel bebas adalah taetap atau telah diukur.

3. Tidak ada korelasi antara variabel bebas.

4. Variasi dari variabel terikat terhadap garis regresi adalah sama untuk nilai semua variabel terikat.

5. Nilai variabel terikat harus tersebar normal atau minimal mendekati normal.

\section{N. Koefisien Determasi $\left(R^{2}\right)$}

Besarnya nilai $\mathrm{R}^{2}$ menyatakan proporsi total variasi yang dapat dijabarkan melalui persamaan regresi-linear yang diperoleh, dimana apabila nilai $\mathrm{R}^{2}=0$, maka persamaan regresi sama sekali tidak dapat menjelaskan variasi yang ada. Jika $\mathrm{R}^{2}=1$ berarti persamaan regresi yang diperoleh secara sempurna mampu menjelaskan variasi yang ada (Hamdi, 2009).

Akan tetapi dengan tambahan biasanya meningkatkan nilai $\mathrm{R}^{2}$; untuk mengatasinya digunakan nilai $\mathrm{R}^{2}$ yang telah dikoreksi (Tamin, 2008;26). Yaitu :

$$
\begin{aligned}
& -\left(R^{2}-\begin{array}{c}
K \\
N-1
\end{array}\right) \\
& -\left(\begin{array}{c}
(N-1) \\
(N-K-1
\end{array}\right)
\end{aligned}
$$

Koefisien determasi $\left(\mathrm{R}^{2}\right)$. Menyatakan besarnya pengaruh dan variabel-variabel bebas terhadap variabel tak bebas.

\section{O. Uji Kelayakan Model (Uji F)}

Uji Linearitas disebut juga dengan uji $F$, pengujian ini diperlukan untuk mengetahui dan memastikan apakah model bangkitan perjalanan dapat dilakukan dengan analisis regresi linear atau analisis regresi non linear. Dalam pengujian ini akan diketahui apakah variabel tak bebas dari model mempunyai hubungan yang linier dengan variabel-variabel bebasnya

\section{P. Uji Hipotesis (Uji t)}

Parameter statistik $\mathrm{t}$ digunakan untuk menguji keberartian koefisien regresi, nilai $\mathrm{t}$ merupakan rasio antara koefisien persamaan regresi dan standar error untuk masing-masing variabel bebas. Pengujian dilakukan dengan membandingkan $t$ tabel dengan $t$ hitung dapat ditentukan dengan rumus (Sujana 1992). 


\section{Q. Metode Penelitian}

1. Tahapan Penelitian

Untuk mendapatkan hasil penelitian yang sesuai dengan tujuan, perlu disusun tahap-tahap yang harus dilakukan. Tahap-tahap kegiatan tersebut disusun berdasarkan hierarki logis, yang menunjukan bahwa urutan-urutan kegiatan saling memliliki ketergantungan, yaitu :

a. Mengindentifikasi masalah, tujuan dan ruang lingkung agar penelitian mencapai tujuan sesuai dengan rencana dan tepat sasaran.

b. Melakukan studi literatur dan kajian-kajian penelitian sejenis yang pernah dilakukan terdahulu yang berhubungan dengan permasalahan yang diangkat.

c. Penelitian pendahuluan terhadap lokasi yang menjadi objek penelitian dengan maksud memperoleh gambaran awal tentang kondisi lokasi untuk menjadi bahan masukan bagi tahap selanjutnya.

d. Diidentifikasi parameter-parameter penelitian yang paling mewakili guna memberikan gambaran.

e. Pembuatan quisioner yang berisikan parameterparameter yang kemudian dapat diubah menjadi variabel-variabel penelitian.

f. Pengumpulan dan pengolahan data.

g. Analisis pembahasan.

\section{Penentuan Variabel Penelitian}

Sebagaimana berpedoman kepada tujuan penelitian lokasi yang diteliti, maka variabel yang ditetapkan terhadap bangkitan perjalanan perumahan Villa Indah Permai dan Villa Dago Permai, yaitu :

Variabel-variabel karakteristik rumah tangga yang diteliti adalah

$Y=a+a 1 \times 1+a 2 \times 2+a 3 \times 3+a 4 \times 4+a 5 \times 5+e$

Dimana :

Y : Jumlah Perjalanan

a : Konstanta

a1: Koefisien Regresi

x1: Jumlah Pendapatan Keluarga

x2: Jumlah Anggota Keluarga Dalam Satu KK

x3: Umur Kepala Keluarga

x4: Jumlah Kepemilikan Roda 4

x5: Jumlah Kepemilikan Roda 2

x6: Jenis Pekerjaan Kepala Keluarga

\section{Penentuan Jumlah Sampel Penelitian}

Penelitian yang dilakukan menyangkut perilaku anggota keluarga yang tinggal di kawasan perumahan Villa Indah Permai dan Villa Dago Permai dalam melakukan perjalanan sesuai dengan tujuan masingmasing. Jadi sampel penelitian yang diambil adalah keluarga-keluarga yang bermukiman di perumahan tersebut.

Dalam penelitian ini pengambilan sampel dilakukan dengan cara stratified random sampling, yang mana bertujuan untuk mendapatkan hasil maksimal agar dapat menjadi bahan pertimbangan bagi perencanaan pemerintah dalam menentukan kebijakan terhadap masalah bangkitan perjalanan.

Menurut tabel Krecjie (Sugiyono, 2007), untuk jumlah populasi (N) maka jumlah sampel (n) minimum sebanyak $40 \%$. Dalam penelitian ini jumlah sampel yang diambil adalah 226 buah, $40 \%$ dari 550 populasi dengan asumsi bahwa semakin besar jumlah sampelnya maka hasilnya akan lebih mendekati kenyataan.

Dimana :

$\mathrm{N}$ : Jumlah Populasi

$\mathrm{n}$ : Jumlah sampel

4. Pembuatan Quesioner

Berdasarkan hasil identifikasi variabel penelitian dan tetap berpedoman kepada tujuan dan penelitian ini, maka disusun daftar pertanyaan dalam bentuk quesioner. Quesioner dirancang dengan maksud untuk memperoleh informasi mengenai karakteristik keluarga, seperti jumlah perjalanan, jumlah anggota keluarga, umur kepala keluarga, kepemilikan mobil, kepemilikan sepeda motor, jumlah penghasilan keluarga, jenis pekerjaan kepala keluarga. Informasi perjalanan seperti tujuan, waktu, moda transport yang digunakan dan rute jalan yang dipilih. Setiap pertanyaan disusun sedemikian rupa sehingga responden tidak mengalami kesulitan dalam menjawab pertanyaan-pertanyaan yang diberikan. Daftar pertanyaan quesioner selengkapnya dapat dilihat pada lampiran.

\section{Kebutuhan Data}

Data yang dibutuhkan menyangkut data primer. Data primer menyangkut data utama yang dibutuhkan untuk dianalisis yang berasal dari sumber langsung.

\section{R. Teknik Pengumpulan Data}

1. Data Quesioner

Pengumpulan data dilakukan dengan metode penyebaran quesioner dan dengan wawancara keluarga. Wawancara keluarga dilakukan dengan maksud untuk mendapatkan informasi langsung perihal daftar pertanyaan yang terdapat pada lembar quesioner. Yang ingin didapat dari pertanyaan quesioner yang ada dengan mengidentifikasi karakteristik dan faktor yang berpengaruh terhadap bangkitan perjalanan penduduk perumahan Villa Indah Permai, Villa Dago Permai, Niagara Hill dan Kemiling Permai, yaitu :

a. Mengetahui berapakah jumlah perjalanan dalam satu keluarga.

b. Berapakah jumlah anggota keluarga dalam satu KK.

c. Mengetahui berapa jumlah penghasilan keluarga dalam satu bulan.

d. Mengetahui Umur Kepala Keluarga.

e. Mengetahui berapa jumlah kepemilikan mobil dalam satu keluarga.

f. Mengetahui berapa jumlah kepemilikan motor dalam satu keluarga.

g. Mengetahui jenis pekerjaan kepala keluarga.

Data primer didapat dengan melakukan metode survey quesioner. 
2. Data Lalu Lintas Harian Rata-rata

Data lalu-lintas harian rata-rata diperoleh guna mengetahui fluktuasi Satuan Mobil Penumpang (SMP) per jam, dengan cara survey lalu lintas. Survey kawasan perumahan Villa Indah Permai dan Villa Dago Permai dilakukan pada gerbang utama yang dilewati oleh penduduk, yang mana diasumsikan sebagai tempat bangkitan perjalanan perumahan tersebut.

\section{Analisa dan Pembahasan}

Untuk menganalisa data dengan menggunakan deskriptif kualitatif. Analisa regresi berguna untuk mengetahui model bangkitan perjalanan dan model yang didapat bisa diketahui faktor-faktor yang mempengaruhi bangkitan perjalanan serta memprediksi kondisi lalu lintas perumahan Villa Indah Permai dan Villa Dago Permai. Untuk memperoleh hasil yang maksimal dan mempermudah pengolahan data, maka dalam proses analisa menggunakan perangkat lunak komputer dengan program SPSS (Statistical Product and Service Solution).

\section{S. Waktu Penelitian}

Proses penelitian yang dilaksanakan, direncanakan selesai dalam waktu enam bulan. Mulai dari penyusunan pada proposal bulan Mei tahun 2015 sampai menyelesaikan laporan skripsi pada bulan September tahun 2015,

\section{T. Tempat Penelitian}

Penelitian ini dilakukan pada perumahan Villa Indah Permai dan Villa Dago Permai di Kecamatan Baturaja Timur Kabupaten OKU. Berikut gambaran lokasi perumahan yang menjadi tempat penelitian :

\section{Pembahasan}

\section{A. Pengolahan DataLalu Lintas Harian Rata-rata (LHR)}

Berdasarkan tujuan penelitian ini yaitu mengetahui fluktuasi / jam puncak kendaraan dalam satuan mobil penumpang (SMP) per jam, maka dilakukan pengamatanterhadapbangkitan kendaraandi gerbang perumahan Villa Indah Permai dan Villa Dago Permai selama 7 hari pada tiap-tiap perumahan dari pukul 06.00-17.00 wib terhitung mulai 17 - 30 Agustus untuk mengetahui sebagaimana jalan tersebut mengalami jam puncak kepadatan.

\section{B. Analisis Data Kuisioner}

Dari hasil wawancara dan pengisian kuisioner oleh responden diperoleh data pergerakan serta data lainnya yang berkaitan dengan bangkitan perjalanan diperumahan Villa Indah Permai dan Villa Dago Permai yang terletak dikecamatan Baturaja Timur kabupaten Ogan Komering Ulu. Responden adalah setiap individu yang bertempat tinggal dalam wilayah perumahan dan melakukan aktifitas secara tetap berlokasi diwilayah tersebut.

\section{Pemodelan Bangkitan}

Pemodelan dalam penelitian ini harus menyeleksi variabel apa saja yang layak dan tidak layak dimasukkan dalam persamaan. Dengan demikian akan diperoleh kombinasi variabel bebas terbaik yang akan menyusun persamaan regresi yang memenuhi persyaratan model secara statistik. Penyeleksian ini dilakukan dengan mengevaluasi beberapa besaran statistik yang diperoleh dengan menganalisis data-data yang diperoleh dari lapangan. Data yang telah terkumpul selanjutnya dipilih menjadi kandidat perubah bebas untuk kebutuhan analisis regresi selanjutnya. Dari data yang diperoleh melalui kuisioner yang kemudian diolah dengan regresi berganda menggunakan bantuan software SPSS.

Dari hasil pengumpulan dan pemilihan data variabel bebas (berupa data kependudukan, sosial, ekonomi, transportasi, dsb) serta variabel tidak bebas (data trip dan perjalanan berdasarkan maksud perjalanan), maka selanjutnya dilakukan uji korelasi data-data tersebut. Uji korelasi diperlukan untuk menilai hubungan antara variabel bebas dan variabel tidak bebas serta antara hubungan sesama variabel bebasnya. Langkah selanjutnya setelah uji korelasi adalah kalibrasi persamaan model yaitu proses penentuan nilai-nilai koefisien persamaan. Untuk kalibrasi persamaan model ini digunakan metode regresi linear berganda.

\section{Analisis Data Perumahan Villa Indah Permai}

1. Statistik Deskriptif

Statistik Deskriptif dilakukan dengan tujuan untuk mengenali pola sejumlah data, merangkum informasi dalam data tersebut, menyajikan informasi tersebut dalam bentuk yang diinginkan. Tabel berikut menyajikan statistik data-data yang diperoleh:

Tabel 1. Statistik Deskriptif

\begin{tabular}{|l|c|c|c|c|c|}
\hline & $\mathrm{N}$ & Minimum & Maximum & Mean & $\begin{array}{c}\text { Std. } \\
\text { Deviation }\end{array}$ \\
\hline Jumlah perjalanan & 72 & 1 & 5 & 2.43 & 1.059 \\
Penghasilan & 72 & 1 & 5 & 2.51 & 1.222 \\
Anggota keluarga & 72 & 1 & 5 & 3.06 & .991 \\
Umur kepala & 72 & 1 & 5 & 3.32 & 1.046 \\
keluarga & 72 & 2 & 5 & 4.42 & .818 \\
Kendaraan roda & 72 & 1 & 5 & 3.33 & .949 \\
empat & 72 & 1 & 5 & 3.78 & 1.141 \\
Kendaraan roda dua & 72 & & & & \\
Jenis Pekerjaan & & & & \\
Valid N (listwise) & 72 & & & \\
\hline
\end{tabular}

Sumber : Hasil pengolahan data 2015

\section{Regresi Linear Berganda}

Analisa regresi digunakan untuk mengetahui bagaimana variabel dependent (bebas) secara parsial secara parsial ataupun secara bersama - sama (simultan). Adapun data data yang di ambil yaitu :

$\mathrm{Y}$ : Jumlah perjalanan anggota keluarga dalam satu KK

$\mathrm{X} 1$ : Penghasilan kepala keluarga

X2 : Jumlah anggota keluarga

X3 : Umur kepala keluarga

X4 : Kepemilikan kendaraan roda empat

X5 : Kepemilikan kendaraan roda dua

X6 : Jenis pekerjaan kepala keluarga 
Proses perhitungan statistic pada penelitian ini menghasilkan beberapa bilangan statistic yang dapat di tampilkan secara bersamaan, antara harga koefisien korelasi, koefisien determinas $\mathrm{R}^{2}$, harga koefisien $\mathrm{F}$, dan besaran statistic lainya.

\section{Koefisien Determinasi $\left(\mathrm{R}^{2}\right)$}

Ujikoefisien Determinasi ( $\mathrm{R}^{\mathbf{2}}$ ) dilakukan untuk melihat seberapa besar variabel independen dapat menjelaskan variabel dependen. Jika dalam uji empiris koefisien determasi sama dengan 0 (adjusted $\mathrm{R}^{2}=0$ ), artinya variasi dari Y tidak dapat diterapkan oleh $\mathrm{X}$ sama sekali. Sementara apabila adjusted $\mathrm{R}^{2}=1$, atinya variasi $\mathrm{Y}$ secara keseluruhan dapat diterangkan oleh $\mathrm{X}$, dengan kata lain bila adjusted $\mathrm{R}^{2}=1$, maka semua titik pengamatan berada tepat pada garis regresi (Ghozali,2011). Hasil dari uji koefisien determasi dapat dilihat pada tabel berikut:

Tabel 2. Koefisien Determasi

\begin{tabular}{|l|l|l|l|l|}
\hline Model & $\mathrm{R}$ & $\mathrm{R}$ Square & $\begin{array}{l}\text { Adjusted R } \\
\text { Square }\end{array}$ & $\begin{array}{l}\text { Std. Error of the } \\
\text { Estimate }\end{array}$ \\
\hline 1 & $.791^{\mathrm{a}}$ & .625 & .590 & .678 \\
\hline
\end{tabular}

Sumber : Hasil pengolahan data 2015

Berdasarkan tabel 4.33 di dapat harga $\mathrm{R}=0.791$ dan koefisien ( $\mathrm{R}$ square ) sebesar 0.625 hal ini menunjukkan pengertian bahwa tarikan pergerakan perjalanan $(\mathrm{Y})$ dipengaruhi sebesar $0.625 * 100 \%=$ $62.5 \%$. Artinyapenghasilan kepala keluarga, jumlah anggota keluarga, umur kepala keluarga, kepemilikan mobil, kepemilikan motor, serta jenis pekerjaan kepala keluarga dijelaskan oleh variabel dependen sebesar $62,5 \%$ sedangkan sisanya $37,5 \%$ ditentukan oleh faktorfaktor lainnya.

\section{Uji kelayakan model (Uji F)}

Berikut adalah hasil pengujian kelayakan model dengan statik $\mathrm{F}$ dalam penelitian ini:

Tabel 3. Uji statistik $F$

\begin{tabular}{|l|l|l|l|l|l|}
\hline \multicolumn{1}{|l|}{ Model } & $\begin{array}{l}\text { Sum of } \\
\text { Squares }\end{array}$ & df & $\begin{array}{l}\text { Mean } \\
\text { Square }\end{array}$ & F & Sig. \\
\hline $1 \quad$ Regression & 49.784 & 6 & 8.297 & 18.056 & $.000^{\mathrm{a}}$ \\
Residual & 29.869 & 65 & .460 & & \\
Total & 79.653 & 71 & & & \\
\hline
\end{tabular}

Sumber : Hasil pengolahan data 2015

Uji kelayakan model dilakukan untuk mengetahui apakah model regresi layak atau tidak untuk digunakan. Pada pengujian ini ditetapkan nilai signifikan sebesar $5 \%$. Hal ini menunjukkan jika nilai signifikasi kurang atau sama dengan 0,05 maka model pengujian ini layak digunakan dan jika nilai signifikasi lebih dari 0,05 maka model pengujian ini tidak layak digunakan.
5. Uji Hipotesis (Uji T)

Berikut adalah hasil pengujian hipotesis uji $\mathrm{T}$ dalam penelitian ini :

Tabel 4. Uji Hipotesis (Uji T)

\begin{tabular}{|c|c|c|c|c|c|}
\hline \multirow[t]{2}{*}{ Model } & \multicolumn{2}{|c|}{$\begin{array}{l}\text { Unstandardized } \\
\text { Coefficients }\end{array}$} & \multirow{2}{*}{$\begin{array}{c}\text { Standardized } \\
\text { Coefficients } \\
\text { Beta }\end{array}$} & \multirow[t]{2}{*}{$\mathrm{t}$} & \multirow[t]{2}{*}{ Sig. } \\
\hline & B & Std. Error & & & \\
\hline 1 (Constant) & -2.409 & .667 & & -3.611 & .001 \\
\hline Penghasilan & .226 & .069 & .260 & 3.287 & .002 \\
\hline $\begin{array}{l}\text { Anggota } \\
\text { keluarga }\end{array}$ & -.131 & .082 & -.123 & -1.602 & .114 \\
\hline $\begin{array}{l}\text { Umur } \\
\text { kepala } \\
\text { keluarga }\end{array}$ & -.088 & .080 & -.087 & -1.100 & .275 \\
\hline $\begin{array}{l}\text { Kendaraan } \\
\text { roda empat }\end{array}$ & .567 & .103 & .438 & 5.522 & .000 \\
\hline $\begin{array}{l}\text { Kendaraan } \\
\text { roda dua }\end{array}$ & .637 & .090 & .571 & 7.096 & .000 \\
\hline $\begin{array}{l}\text { Jenis } \\
\text { Pekerjaan }\end{array}$ & .089 & .072 & .096 & 1.237 & .220 \\
\hline
\end{tabular}

Sumber : Hasil pengolahan data 2015

Penguji pada tabel 4.35. dapat menjawab hipotesis pertama, yaitu pengungkapan penghasilan berpengaruh signifikan terhadap bangkitan perjalanan. Pengujian dilakukan dengan menggunakan uji $\mathrm{T}$ pada tingkat keyakinan $95 \%$ atau a sebesar 0,05 dari hasil output SPSS yang diperoleh, seperti yang tercantum pada tabel 4.21. Apabila $\mathrm{t}$ - hitung lebih besar dati $\mathrm{t}$ - tabel $(\mathrm{th}>\mathrm{tt})$ maka Ho ditolak dan Ha diterima, sebaliknya apabila $t$ hitung lebih kecil dari $\mathrm{t}$ - tabel $(\mathrm{th}<\mathrm{tt})$ maka Ho diterima dan Ha ditolak, atau dengan tingkat signifikasi (sig.)< 0,05 maka Ho ditolak diterima Ha, sebaliknya signifikasi (sig.) > 0,05 maka Ho diterima dan Ha ditolak. Dari tabel tersebut terlihat bahwa untuk :

a. Hasil uji hipotesis pengaruh penghasilan terhadap bangkitan perjalanan.

$\mathrm{T}$ hitung sebesar 3,287 lebih besar dari t tabel 1,99656 dan dengan tingkat signifikasi sebesar 0,002 $<$ 0,05. Dengan demikian Ha diterima dan Ho ditolak, yang berarti mempunyai pengaruh terhadap bangkitan perjalanan perumahan Villa Indah Permai.

b. Hasil uji hipotesis pengaruh Jumlah anggota keluarga terhadap bangkitan perjalanan.

$\mathrm{T}$ hitung sebesar -1,602 lebih kecil dari t tabel 1,99656dan dengan tingkat signifikasi sebesar 0,114 $>$ 0,05. Dengan demikian Ho diterima dan $\mathrm{Ha}$ ditolak, yang berarti tidak mempunyai pengaruh terhadap bangkitan perjalanan perumahan Villa Indah Permai.

c. Hasil uji hipotesis pengaruh umur kepala keluarga keluarga terhadap bangkitan perjalanan.

$\mathrm{T}$ hitung sebesar $-1,100$ lebih kecil dari t tabel 1,99656dan dengan tingkat signifikasi sebesar $-1,100$ $<0,05$. Dengan demikian Ho diterima dan $\mathrm{Ha}$ ditolak, yang berarti tidak mempunyai pengaruh terhadap bangkitan perjalanan perumahan Villa Indah Permai. 
d. Hasil uji hipotesis pengaruh kendaraan roda empat terhadap bangkitan perjalanan.

$\mathrm{T}$ hitung sebesar 5,552 lebih besar dari t tabel 1,99656dan dengan tingkat signifikasi sebesar $0,000<$ 0,05. Dengan demikian Ha diterima dan Ho ditolak, yang berarti mempunyai pengaruh terhadap bangkitan perjalanan perumahan Villa Indah Permai.

e. Hasil uji pengaruh kendaraan roda dua terhadap bangkitan perjalanan.

$\mathrm{T}$ hitung sebesar 7,096 lebih besar dari t tabel 1,99656dan dengan tingkat signifikasi sebesar 0,000< 0,05. Dengan demikian Ha diterima dan Ho ditolak, yang berarti mempunyai pengaruh terhadap bangkitan perjalanan perumahan Villa Indah Permai.

f. Hasil uji hipotesis pengaruh pekerjaan kepala keluarga terhadap bangkitan perjalanan.

$\mathrm{T}$ hitung sebesar 1,237 lebih kecil dari t tabel 1,99656dan dengan tingkat signifikasi sebesar 0,220< 0,05. Dengan demikian Ha diterima dan Ho ditolak, yang berarti mempunyai pengaruh terhadap bangkitan perjalanan perumahan Villa Indah Permai.

\section{E. Analisis Data Perumahan Villa Dago Permai}

1. Statistik Deskriptif

Statistik Deskriptif dilakukan dengan tujuan untuk mengenali pola sejumlah data, merangkum informasi dalam data tersebut, menyajikan informasi tersebut dalam bentuk yang diinginkan.

\section{Uji Asumsi Klasik}

Persyaratan untk bisa menggunakan persamaan regresi berganda adalah tepenuhnya asumsi klasik. Untuk mendapatkan nilai yang efisien dan tidak bias atau BLUE (Best Linear Unbias Estimator) dari satu persamaan regresi berganda, maka perlu dilakukan pengujian untuk mengetahui model regresi yang dihasilkan memenuhi persyaratan asumsi klasik.

a. Uji Normalitas

Uji normalitas bertujuan menguji apakah dalam model penelitian variabel terdistribusi secara normal atau tidak. Model regresi yang baik adalah model regresi yang memiliki distribusi nilai residual normal atau mendekati normal, Uji normalitas data dalam penelitian ini menggunakan pengujian one sample kolmogrov smirnov test. Hasil uji normalitas dapat dilihat pada tabel beriku ini :

Tabel 5. Uji Normalitas

\begin{tabular}{|ll|c|}
\hline & & $\begin{array}{c}\text { Unstandardized } \\
\text { Residual }\end{array}$ \\
\hline $\mathrm{N}$ & & 58 \\
Normal Parameters $^{\mathrm{a}}$ & Mean & .0000000 \\
& Std. Deviation & .79784451 \\
Most Extreme Differences & Absolute & .082 \\
& Positive & .082 \\
& Negative & -.074 \\
Kolmogorov-Smirnov Z & & .625 \\
Asymp. Sig. (2-tailed) & & .830 \\
\hline
\end{tabular}

Sumber : Hasil pengolahan data 2015
Berdasarkan tabel 4.37. dapat dilihat bahwa tidak terjadi gejala atau non normalitas pada data yang digunakan dalam penelitian ini. Hal ini dapat dilihat dari nilai residualnya yang berada diatas tingkat signifikasinya 0,05 . Oleh karena nilai signifikasi $>0,05$ maka diketahui bahwa data normal atau memenuhi syarat uji normalitas.

Pengujian ini di lakukan dengan cara mendeteksi penyebaran titik pada sumbu diagonal. Apabila titik titik menyebar di sekitar garis diagonal dan mengikuti arah garis tersebut, maka model regresi memenuhi asumsi normalitas. Dari gambar diatas terlihat bahwa data menyebar disekitar garis diagonal menuju pola distribusi normal, sehingga memenuhi asumsi normalitas.

\section{b. Uji Multikolinearitas}

Multikolinearitas terjadi jika nilai tolerance lebih kecil dari 0,10 yang berarti terjadi hubungan yang cukup besar antara variabel bebas dan tidak ada korelasi antar variabel independen yang nilainya lebih dari 95\% (koefisien lemah tidak lebih besar dari 5). Jika VIF lebih besar dari 10, apabila VIF kurang dari 10 dapat dikatakan bahwa variabel independen yang digunakan dalam model adalah dapat dipercaya dan objektif. Hasil uji multikoliniaritas dapat dilihat pada tabel berikut :

Tabel 6. Uji Multikolinearitas

\begin{tabular}{|c|c|c|c|c|c|c|c|}
\hline \multirow[b]{2}{*}{ Model } & \multicolumn{2}{|c|}{$\begin{array}{l}\text { Unstandardi } \\
\text { zed } \\
\text { Coefficients }\end{array}$} & \multirow[t]{2}{*}{$\begin{array}{l}\text { Standa } \\
\text { rdized } \\
\text { Coeffi } \\
\text { cients }\end{array}$} & \multirow[b]{2}{*}{$\mathrm{t}$} & \multirow[t]{2}{*}{ Sig. } & & \\
\hline & B & $\begin{array}{c}\text { Std. } \\
\text { Erro } \\
r\end{array}$ & & & & $\begin{array}{c}\text { Coef } \\
\text { ficie } \\
\mathrm{nt} \\
\mathbf{s}^{\mathbf{a}}\end{array}$ & VIF \\
\hline (Constant) & 1.302 & .679 & & 1.918 & .061 & & \\
\hline $\mathrm{X} 1$ & .318 & .097 & .289 & 3.282 & .002 & .866 & 1.154 \\
\hline $\mathrm{X} 2$ & .044 & .106 & .036 & .414 & .681 & .873 & 1.146 \\
\hline X3 & .406 & .123 & .290 & 3.302 & .002 & .874 & 1.144 \\
\hline $\mathrm{X} 4$ & .685 & .107 & .535 & 6.386 & .000 & .962 & 1.039 \\
\hline $\mathrm{X} 5$ & -.301 & .119 & -.230 & -2.525 & .015 & .812 & 1.232 \\
\hline X6 & -.500 & .105 & -.427 & -4.765 & .000 & .838 & 1.193 \\
\hline
\end{tabular}

Sumber : Hasil pengolahan data 2015

Berdasarkan nilai VIF yang diperoleh seperti pada tabel 4.38. di atas menunjukkan tidak ada korelasi yang cukup antara sesama variabel bebas, dimana nilai VIF dari kedua variabel bebas lebih kecil dari 10 dan dapat disimpulkan tidak terjadi multikolinearitas diantara variabel bebas. Dengan demikian model regresi yang diperoleh tidak terdapat problem multikolinearitas.

c. Uji Autokeralasi

Uji Autokorelasi digunakan untuk melihat apakah dalam Model regresi terdapat ganguan korelasi atau tidak diantara variabel bebas dan terikat.Untuk menguji adanya autokorelasi diantara variabel - variabel bebas, dilakukan dengan pengujian Durbin - Watson sebagai berikut : 
Menduga terjadi tidaknya autokorelasi dengan diagram antara grafik antara et dengan et -1 sangat sulit.

Tabel 7. Uji Autokorelasi

\begin{tabular}{|c|c|c|c|c|c|}
\hline Model & $\mathrm{R}$ & R Square & $\begin{array}{c}\text { Adjusted } \\
\text { R Square }\end{array}$ & $\begin{array}{c}\text { Std. Error } \\
\text { of the } \\
\text { Estimate }\end{array}$ & $\begin{array}{c}\text { Durbin- } \\
\text { Watson }\end{array}$ \\
\hline 1 & $.810^{\mathrm{a}}$ & .656 & .616 & .822 & 2.256 \\
\hline
\end{tabular}

Sumber : Hasil pengolahan data 2015

Pada tabel output data dapat terlihat nilai D - W yaitu sebesar 2.256,untuk menguji adanya autokorelasi diantara variabel variabel bebas maka dilakukan dengan pengujian Durbin - Watson, sebagai berikut :

Berdasarkan tabel yang di peroleh dari tabel Durbin Watson :

a. Jika d < Dl maka terdapat autokorelasi positif

b. Jika d > Du maka tidak terdapat autokorelasi positif

c. Jika $\mathrm{Dl}<\mathrm{d}<\mathrm{Du}$ maka pengujian tidak terdapat autokorelasi positif.

Berdasarkan hasil pengujian dari Durbin - Watson dengan menggunakan program SPSS diperoleh nilai D$\mathrm{W}$ sebesar 2.256. Ternyata nilai $\mathrm{D}-\mathrm{W}=2.256>1,8151$ (lihat tabel D-W) yang artinya tidak terdapat autokorelasi positif..

d. Uji Heterokedastisitas

Jika variance (ragam) dari residual satu ke pengamatan lain tetap, maka disebut homoskedastisitas atau tidak terjadi heteroskadasitas. Untuk mendeteksi ada tidaknya heteroskadastisitas dilakukan dengan melihat ada tidaknya pola tertentu pada grafik scatterplot antar SRESID dan ZPRED dimana sumbu X adalah Y yang telah diprediksi, sumbu $\mathrm{x}$ adalah residual ( $\mathrm{Y}$ prediksi - Y sesungguhnya) yang telah di studentized (Ghozali, 2011).

Gambar diatas menunjukan hasil pengujian heteroskadastisitas pada tampilan grafik scatterplots bahwa titik-titik tidak berkumpul dan menyebar secara acak baik diatas maupun dibawah angka $\mathrm{O}$ pada sumbu Y. Hal ini dapat disimpulkan bahwa tidak terjadi heteroskadastisitas pada model regresi penelitian ini.

\section{Regresi Linear Berganda}

Analisa regresi digunakan untuk mengetahui bagaimana variabel dependent ( bebas ) secara parsial secara parsial ataupun secara bersama - sama (simultan). Adapun data data yang di ambil yaitu :

Y : Jumlah perjalanan anggota keluarga dalam satu KK

$\mathrm{X} 1$ : Penghasilan kepala keluarga

$\mathrm{X} 2$ : Jumlah anggota keluarga

X3 : Umur kepala keluarga

X4 : Kepemilikan kendaraan roda empat

X5 : Kepemilikan kendaraan roda dua

X6 : Jenis pekerjaan kepala keluarga

Proses perhitungan statistik pada penelitian ini menghasilkan beberapa bilangan statistic yang dapat di tampilkan secara bersamaan, antara harga koefisien korelasi, koefisien determinas $\mathrm{R}^{2}$, harga koefisien $\mathrm{F}$, dan besaran statistik lainya.
4. Koefisien Determinasi ( $\left.\mathrm{R}^{2}\right)$

Ujikoefisien Determinasi ( $\mathrm{R}^{2}$ ) dilakukan untuk melihat seberapa besar variabel independen dapat menjelaskan variabel dependen. Jika dalam uji empiris koefisien determasi sama dengan 0 (adjusted $\mathrm{R}^{2}=0$ ), artinya variasi dari $\mathrm{Y}$ tidak dapat diterapkan oleh $\mathrm{X}$ sama sekali. Sementara apabila adjusted $\mathrm{R}^{2}=1$, artinya variasi $\mathrm{Y}$ secara keseluruhan dapat diterangkan oleh $\mathrm{X}$, dengan kata lain bila adjusted $\mathrm{R}^{2}=1$, maka semua titik pengamatan berada tepat pada garis regresi (Ghozali,2011). Hasil dari uji koefisien determasi dapat dilihat pada tabel berikut:

Tabel 8. Uji Koefisien Determasi

\begin{tabular}{|c|c|c|c|c|c|}
\hline Model & $\mathrm{R}$ & $\begin{array}{c}\mathrm{R} \\
\text { Square }\end{array}$ & $\begin{array}{c}\text { Adjuste } \\
\mathrm{d} \mathrm{R} \\
\text { Square }\end{array}$ & $\begin{array}{c}\text { Std. Error } \\
\text { of the } \\
\text { Estimate }\end{array}$ & $\begin{array}{c}\text { Durbin- } \\
\text { Watson }\end{array}$ \\
\hline 1 & $.810^{\mathrm{a}}$ & .656 & .616 & .822 & 2.256 \\
\hline
\end{tabular}

Sumber : Hasil pengolahan data 2015

Berdasarkan tabel 4.40. di dapat harga $\mathrm{R}=0.791$ dan koefisien ( $\mathrm{R}$ square ) sebesar 0.656 hal ini menunjukkan pengertian bahwa tarikan pergerakan perjalanan ( Y ) dipengaruhi sebesar $0.656 * 100 \%=$ 65.6\%. Artinyapenghasilan kepala keluarga, jumlah anggota keluarga, umur kepala keluarga, kepemilikan mobil, kepemilikan motor, serta jenis pekerjaan kepala keluarga dijelaskan oleh variabel dependen sebesar $65,6 \%$ sedangkan sisanya $34,4 \%$ ditentukan oleh faktorfaktor lainnya.

\section{Uji kelayakan model (Uji F)}

Berikut adalah hasil pengujian kelayakan model dengan statik $\mathrm{F}$ dalam penelitian ini :

Tabel 9. Uji statistik $F$

\begin{tabular}{|ll|c|c|c|c|c|}
\hline \multicolumn{1}{|c|}{ Model } & $\begin{array}{c}\text { Sum of } \\
\text { Squares }\end{array}$ & df & $\begin{array}{c}\text { Mean } \\
\text { Square }\end{array}$ & F & Sig. \\
\hline 1 Regression & 49.784 & 6 & 8.297 & 18.056 & $.000^{\mathrm{a}}$ \\
& Residual & 29.869 & 65 & .460 & & \\
Total & 79.653 & 71 & & & \\
\hline
\end{tabular}

Sumber : Hasil pengolahan data 2015

Uji kelayakan model dilakukan untuk mengetahui apakah model regresi layak atau tidak untuk digunakan. Pada pengujian ini ditetapkan nilai signifikan sebesar 5\%. Hal ini menunjukkan jika nilai signifikasi kurang atau sama dengan 0,05 maka model pengujian ini layak digunakan dan jika nilai signifikasi lebih dari 0,05 maka model pengujian ini tidak layak digunakan.

6. Uji Hipotesis (Uji T)

Berikut adalah hasil pengujian hipotesis uji $\mathrm{T}$ dalam penelitian ini : 
Tabel 10. Uji Hipotesis (Uji T)

\begin{tabular}{|c|c|c|c|c|c|}
\hline \multirow[b]{2}{*}{ Model } & \multicolumn{2}{|c|}{$\begin{array}{c}\text { Unstandardized } \\
\text { Coefficients }\end{array}$} & \multirow{2}{*}{\begin{tabular}{|c}
$\begin{array}{l}\text { Standa } \\
\text { rdized } \\
\text { Coeffi } \\
\text { cients }\end{array}$ \\
Beta
\end{tabular}} & \multirow[b]{2}{*}{$\mathrm{t}$} & \multirow[b]{2}{*}{ Sig. } \\
\hline & B & Std. Error & & & \\
\hline 1 (Constant) & 1.302 & 679 & & 1.918 & .061 \\
\hline Penghasilan & .318 & .097 & .289 & 3.282 & .002 \\
\hline $\begin{array}{l}\text { Jumlah } \\
\text { anggota } \\
\text { keluarga }\end{array}$ & .044 & .106 & .036 & .414 & .681 \\
\hline $\begin{array}{l}\text { Umur } \\
\text { kepala } \\
\text { keluarga }\end{array}$ & .406 & .123 & .290 & 3.302 & .002 \\
\hline $\begin{array}{l}\text { Kendaraan } \\
\text { roda empat }\end{array}$ & .685 & .107 & .535 & 6.386 & .000 \\
\hline $\begin{array}{l}\text { Kendaraan } \\
\text { roda dua }\end{array}$ & -.301 & .119 & -.230 & -2.525 & .015 \\
\hline $\begin{array}{l}\text { Jenis } \\
\text { pekerjaan }\end{array}$ & -.500 & .105 & -.427 & -4.765 & .000 \\
\hline
\end{tabular}

Sumber : Hasil pengolahan data 2015

Penguji pada tabel 4.42. dapat menjawab hipotesis pertama, yaitu pengungkapan penghasilan berpengaruh signifikan terhadap bangkitan perjalanan. Pengujian dilakukan dengan menggunakan uji $\mathrm{T}$ pada tingkat keyakinan $95 \%$ atau a sebesar 0,05 dari hasil output SPSS yang diperoleh, seperti yang tercantum pada tabel 4.42. Apabila $\mathrm{t}-$ hitung lebih besar dati $\mathrm{t}-$ tabel $(\mathrm{th}>\mathrm{tt})$ maka Ho ditolak dan Ha diterima, sebaliknya apabila $\mathrm{t}-$ hitung lebih kecil dari $\mathrm{t}-$ tabel $(\mathrm{th}<\mathrm{tt})$ maka Ho diterima dan Ha ditolak, atau dengan tingkat signifikasi (sig.)< 0,05 maka Ho ditolak diterima Ha, sebaliknya signifikasi (sig.) > 0,05 maka Ho diterima dan Ha ditolak. Dari tabel tersebut terlihat bahwa untuk :

a. Hasil uji hipotesis pengaruh penghasilan terhadap bangkitan perjalanan.

$\mathrm{T}$ hitung sebesar 3,282 lebih besar dari $\mathrm{t}$ tabel 2,00665dan dengan tingkat signifikasi sebesar 0,002 $<$ 0,05. Dengan demikian Ha diterima dan Ho ditolak, yang berarti mempunyai pengaruh terhadap bangkitan perjalanan perumahan Villa Dago Permai.

b. Hasil uji hipotesis pengaruh Jumlah anggota keluarga terhadap bangkitan perjalanan.

$\mathrm{T}$ hitung sebesar -1,602 lebih kecil dari t tabel 2,00665dan dengan tingkat signifikasi sebesar 0,414> 0,05. Dengan demikian Ho diterima dan Ha ditolak, yang berarti tidak mempunyai pengaruh terhadap bangkitan perjalanan perumahan Villa Dago Permai.

c. Hasil uji hipotesis pengaruh umur kepala keluarga keluarga terhadap bangkitan perjalanan.

$\mathrm{T}$ hitung sebesar 3,302 lebih kecil dari t tabel 2,00665dan dengan tingkat signifikasi sebesar $-1,100$ $<0,05$. Dengan demikian Ha diterima dan Ho ditolak, yang berarti mempunyai pengaruh terhadap bangkitan perjalanan perumahan Villa Dago Permai.

d. Hasil uji hipotesis pengaruh kendaraan roda empat terhadap bangkitan perjalanan.
$\mathrm{T}$ hitung sebesar 6,386 lebih besar dari t tabel 2,00665dan dengan tingkat signifikasi sebesar 0,000 $<0,05$. Dengan demikian $\mathrm{Ha}$ diterima dan $\mathrm{Ho}$ ditolak, yang berarti mempunyai pengaruh terhadap bangkitan perjalanan perumahan Villa Dago Permai.

e. Hasil uji pengaruh kendaraan roda dua terhadap bangkitan perjalanan.

$\mathrm{T}$ hitung sebesar $-2,525$ lebih kecil dari $\mathrm{t}$ tabel 2,00665dan dengan tingkat signifikasi sebesar 0,015 $<0,05$. Dengan demikian Ho diterima dan $\mathrm{Ha}$ ditolak, yang berarti tidak mempunyai pengaruh terhadap bangkitan perjalanan perumahan Villa Dago Permai.

f. Hasil uji hipotesis pengaruh pekerjaan kepala keluarga terhadap bangkitan perjalanan.

$\mathrm{T}$ hitung sebesar $-4,765$ lebih kecil dari $\mathrm{t}$ tabel 2,00665dan dengan tingkat signifikasi sebesar 0,000 $<$ 0,05. Dengan demikian Ho diterima dan $\mathrm{Ha}$ ditolak, yang berarti tidak mempunyai pengaruh terhadap bangkitan perjalanan perumahan Villa Dago Permai.

\section{Kesimpulan}

Berdasarkan pembahasan sebelumnya dapat disimpulkan fluktuasi SMP di perumahan Villa Indah Permai menggunakan sepeda motor yaitu sebanyak 49 $\mathrm{SMP} /$ jam, untuk mini bus 5SMP/jam dan untuk angkutan umum $3 \mathrm{SMP} /$ jam sedangkan fluktuasi perumahan Villa Dago Permai Bangkitan menggunakan sepeda motor yaitu sebanyak $36 \mathrm{SMP} /$ jam, untuk mini bus $9 \mathrm{SMP} /$ jam dan untuk angkutan umum $6 \mathrm{SMP} / \mathrm{jam}$

Model bangkitan perjalanan Villa Indah Permai adalah sebagai berikut :

$Y=-2,049+0,226 . X 1+0,567 . X 4+0,637 . X 5$

1. Berdasarkan hasil uji $\mathrm{t}$ untuk penghasilan (X1) diperolehT hitung sebesar 3,287 lebih besar dari t tabel 1,99656dan dengan tingkat signifikasi sebesar $0,002<0,05$. Dengan demikian Ha diterima dan Ho ditolak.

2. Berdasarkan hasil uji tuntuk kendaraan roda empat. (X4) diperolehT hitung sebesar 5,552 lebih besar dari $\mathrm{t}$ tabel 1,99656dan dengan tingkat signifikasi sebesar $0,000<0,05$. Dengan demikian Ha diterima dan Ho ditolak.

3. Berdasarkan hasil uji $\mathrm{t}$ untuk kendaraan roda dua (X5) diperoleh $\mathrm{T}$ hitung sebesar 7,096 lebih besar dari $t$ tabel 1,99656dan dengan tingkat signifikasi sebesar 0,000 $<0,05$. Dengan demikian Ha diterima dan Ho ditolak, sedangkan Model bangkitan perjalanan Villa Dago Permai adalah sebagai berikut $: Y=1,302+0,318 . X 1+0,406 . X 3+0,685 . X 4$

4. Berdasarkan hasil uji t untuk penghasilan (X1) diperoleh $\mathrm{T}$ hitung sebesar 3,282 lebih besar dari $\mathrm{t}$ tabel 2,00665dan dengan tingkat signifikasi sebesar $0,002<0,05$. Dengan demikian Ha diterima dan Ho ditolak.

5. Berdasarkan hasil uji t untuk umur kepala keluarga (X3) diperoleh T hitung sebesar 3,302 lebih kecil dari $\mathrm{t}$ tabel 2,00665dan dengan tingkat signifikasi sebesar 
$-1,100<0,05$. Dengan demikian Ha diterima dan Ho ditolak.

6. Berdasarkan hasil uji t untuk kendaraan roda empat. (X4) diperoleh $\mathrm{T}$ hitung sebesar 6,386 lebih besar dari t tabel 2,00665dan dengan tingkat signifikasi sebesar $0,000<0,05$. Dengan demikian Ha diterima dan Ho ditolak.

\section{Daftar Pustaka}

Fidel Miro S.E, 2005 Perencanaan Transportasi, Penerbit Erlangga Jakarta

Hardiono, 2013 Analisis Karakteristik Tarikan Pergerakan Pengunjung Wanita Yang Memiliki Sepeda Motor Dengan Pola Pergerakan Rumah Pasar - Rumah DiKota Makassar. Skripsi Teknik Sipil Universitas Hasanudin Makassar.

Intari Dwi Esti, 2012 Karakteristik Dan Bangkitan Perjalanan Zona Terhadap Pusat Perbelanjaan Studi Kasus: Mall Of Serang. Serang

Octavianus Michael, 2013 Bangkitan Perjalanan Pada Perumahan Menteng Indah dikecamatan Medan Denai, Medan

Ofyar Z Tamin, 2000 Perencanaan Pemodelan, Dan rekayasa Transportasi. Penerbit, ITB.

P Widiarta,Ida Bagus.2010Analisis Pemilihan Moda Transportasi Perjalanan Kerja (StudiKasus Badung, Bali).Jurnal Teknik Sipil Universitas Udayana.

Ronny Ronald, 2014 Bangkitan perjalanan pada kawasan perumahan (Studi Kasus BTN 1 Kelurahan Bende Kecamatan Kadia Kota Kendari). Kendari

R.J Pratama, Syafi'I, Legowo 2013 Analisis Pemodelan TarikanPergerakan Bank Dengan Metode Analisis Regresi Linear Berganda (StudiKasus Di Wilayah Surakarta). Jurnal Teknik Sipil Universitas Sebelas Maret Surakarta.

Wikipedia, 2010 Satuan Mobil Penumpang. Penerbit Wikipedia.com

Yusri Bobi Antomi, 2013 Tinjauan bangkitan dan tarikan perjalanan kelurahan keecamatan rambah, pasir pengaraian 